\title{
How to Gain Success in SME? A Case Study of a region in the Czech Republic.
}

\section{Jarmila Sebestova , Zaneta Rylkova, Marek Smysl}

\begin{abstract}
Small and medium sized entrepreneurship (SME) is often considered a contemporary phenomenon. Why have so many authors dedicated their work to this field? The main reason is that SME influences society and contributes to the economic development of its region. This analysis emphasizes endogenous factors for success. The situation in the Moravia-Silesian Region (the northeast region of the (zech Republic) in which we applied factor analysis on a research sample supported our hypothesis. Moreover, we used VRIO analysis to clearly interpret our research findings.
\end{abstract}

JEL: L20, L26

DOI: $10.2478 / v 10033-007-0014-0$

\section{Introduction}

Factors with the power to change current trends in regional development can be divided into two groups according to the environment of their origin - exogenous and endogenous. The EU's definition of small and medium sized entrepreneurship is only a quantitative measurement, an effort to classify a business unit in the market using statistical methods and tests. Gaining an inside qualitative approach to entrepreneurship seems more important for entrepreneurship development and factor analysis of its primary influences..

The main reason for the present work is to share my own research findings in the SME field. Its principal purpose is to identify and describe the endogenous factors which characterize the standard business behavior in a chosen region. The region examined here comprises a territory with the second lowest entrepreneurship activity rate in the Czech Republic (Czech Statistical Office, 2005) given the theory that "SME units are closely connected with the region where they were born". We have to examine entrepreneurship by focusing on the potential of a business unit (what it could offer to society or the market; supply side) and resources for activity development (financing, human resources) in the context of the dynamics and turbulence of the business environment. All these factors cause important changes in strategic entrepreneur behavior (Slávik, 2005).
The analysis is based on statistical data analysis on a descriptive level, representing the quantitative research area (frequency, average values in a one dimensional space; cross tabs with Cramer's contingency coefficient - V); as well as multidimensional statistic methods in the qualitative research area using Principal Components Analysis (PCA). All collected data were processed in SPSS for Windows, ver. 11.5.

Based on the findings of the empirical study, conclusions are made by means of a synthesis of bibliographical sources and the results of the individual factor research defining barriers in the SME sector, especially emphasizing internal factors

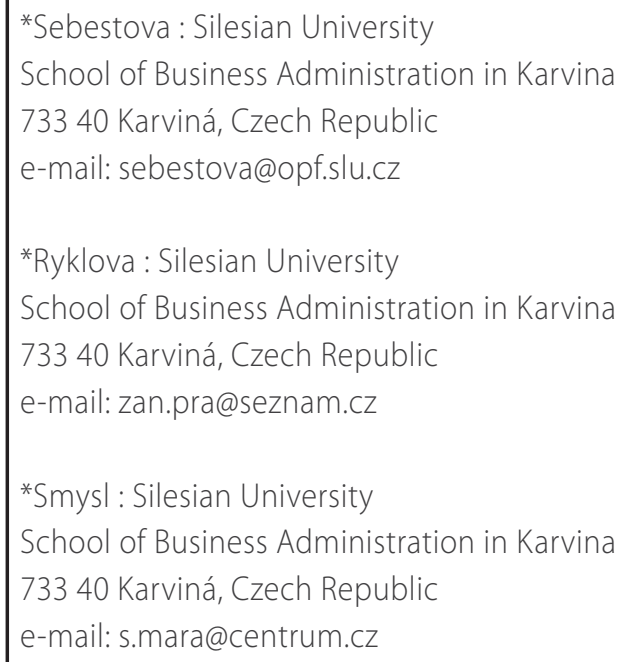


(under the active influence of a business unit). The VRIO strategic method of internal business analysis has been used to classify and interpret the established factors (Barney, 1991) as a source for strategy planning to become more competitive in a globalized business environment.

\section{Entrepreneurship Success Evaluation}

The measurement of entrepreneurship success is a long term process. The process of the optimal utilization of sources and potential was found for the first time in the work of Ricardo (1817), whose ideas were expanded by Penrose (1959) and Wernerfelt (1984). We can include Barney (1986) in this group of authors for his attempts to establish analytic methods to find and interpret business behavior and factors influencing market position and success based on an empirical study.

Barney's theory first poses the question of why some businesses are more successful than others. He compares the strategy types commonly used by business units. The main factor affecting company behavior in a market is imperfect competition. Strategy preparation and its implementation in this business situation could cause growth in the strategy's costs. The tool, identified by Barney, for improvement of the situation is specified as the market of strategic factors dependent on managerial skills and their effective combination and utilization. (Barney, 1986, p.1231).

Barney maintains that each strategic factor bears a different benefit or opportunity for an entrepreneur. We may illustrate his idea as a logical sequence below:

\section{Different strategic factors $=>$}

\section{Product markets in imperfect competition $=>$}

\section{Higher benefits for competitors...}

Following Barney's theory, this sequence highlights the important fact that entrepreneurs have no other option than to evaluate their strategic steps, information sources and their own business potential. He emphasizes confrontation between endogenous activity monitoring and internal source analysis. Barney's conception was criticized and then modified by Dierickx and Cool (1989), who made some recommendations and corrections in its strategic factor analysis. They maintained there existed another factor influencing strategic behavior - a support policy on the part of the government influencing the combination of strategic factors used over the observed time.
They recommend the following items be included in the analysis:

- Seasonal economic fluctuation connected with capital market and capital cost; demonstrating the economic rule stating that over time yields decline in value (in the case of costs taken as constant),

- Effective utilization of total assets - accumulation of as sets results from good asset management,

- Capital and asset connection - accumulation is determined by the variability of capital, which influences debt ratio due to the use of alternative financial resources,

- Decline in asset value - all assets lose their value by depreciation and wear and tear,

- Causal ambiguity (Lippman, Rumelt, 1982) - comes from the Stochastic theory of the accumulative process of strategic activities.

According to this approach, it is necessary to define strategic steps as factors which bring a competitive advantage to each business unit in the market. Barney connected all factors and recommendations in his analysis, calling these VRIO. As resources he defined finances, human capital, individuality and managerial skills. Capacities, by contrast, he referred to as "internal abilities", which coordinate and derive benefit from these (for the analytical scheme of his ideas, see table 1).

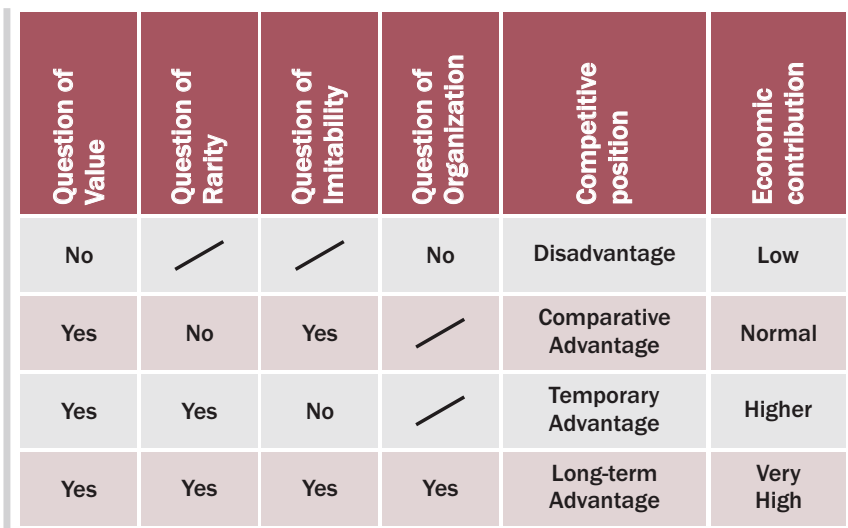

Source: Barney, 1997: 163, modified by auth

\section{Table 1.}

VRIO scheme

We can connect the VRIO parameters with a part of the SWOT analysis as a more popular method for strategic planning, especially strong and weak point comparison (see table 2) 


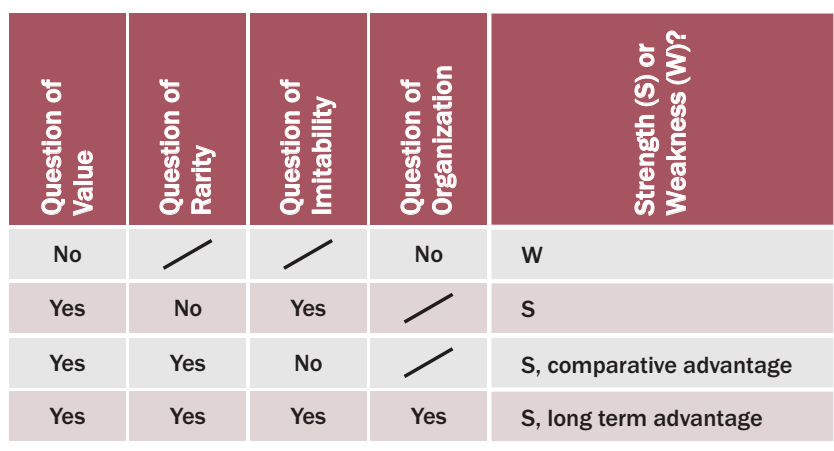

Source: Barney, 1997: 163, modified by author

Table 2.

VRIO and S-W array

According to Barney's theories, this means that capacities or resources which are valuable, imperfectly imitable or rare bring long term advantages in the market, and the economic benefits to society exceed the normal value. Business prosperity is only appraisable in the context of long term analysis (Barney, 1997: 164).

\section{Application of the theory to the Moravia-Silesian Region}

The Moravia-Silesian (MS) Region is situated in the northeastern part of the Czech Republic. The Czech government classifies it as a region with low development tendencies, along with the northwestern region of Ústecko. This classification came from the most recent economic analysis, which stated that the region would not improve in the long term forecast. To be more specific, we may compare the annual GDP rate per one inhabitant in the region at $6981 €(C Z S O, 2005)$, with the GDP rate per one Czech inhabitant of $8503 €$. Both regions have the highest unemployment rate in the Czech Republic. The situation is the result of an unfinished process of economic restructuring. (Plan of National Development 2007-2013, p. 103) After 1990 , the impact on the region from changes in the economic structure, industry revitalization and the decline of coal production was severe (large companies in heavy industry- the region's main historical specialization- were shut down). The current unemployment rate is $14.22 \%$ in 3Q/2006 (CZSO, 2006).

Other authors call this region a dynamic region or a region in progression. Improvements to the environment, infrastructure renovation and the completion of the process of privatization could be an impulse for foreign investors, such as Hyundai. The region has prepared many industrial zones to attract companies and support the transfer of advanced technologies.
The analysis for the SME description was collected in the abovementioned region during 2005 and early 2006 and the questionnaire was distributed to 1800 units; we obtained 1 199 responses by personal visit. We computerized all the data using a statistical method. The main emphasis was placed on the relationship between factors influencing business activities in the region.

\begin{tabular}{|l|r|r|}
\hline \multicolumn{1}{|c|}{ Company type } & Number & Percentage Share \\
\hline Micro (under 10 employees) & 633 & $52.8 \%$ \\
\hline Small (11-49 employees) & 354 & $29.5 \%$ \\
\hline Medium (under 250 employees) & 212 & $17.7 \%$ \\
\hline TOTAL & 1199 & $100 \%$ \\
\hline
\end{tabular}

Source: Barney, 1997: 163, modified by author

\section{Table 3.}

\section{Research sample}

The size of the research sample corresponds to $0.52 \%$ of registered business units in the region in 2005 (229 242), but the Czech Statistical Office (CZSO) states in their SME study that only two thirds of these units actively carry out business activities (CZSO, 2005). Therefore, the percentage of the research sample could cover about $0.8 \%$ of all registered units.

The first factor we addressed was that of time, which could influence business behavior today. The period of operating in the regional market could show a relationship between the competitiveness of SME units and their effective work with capacities and resources. The graph below shows that more than 65\% of examined units had been established before 1995. It demonstrates that owners know their business environment sufficiently and have discovered a strategy to survive in the
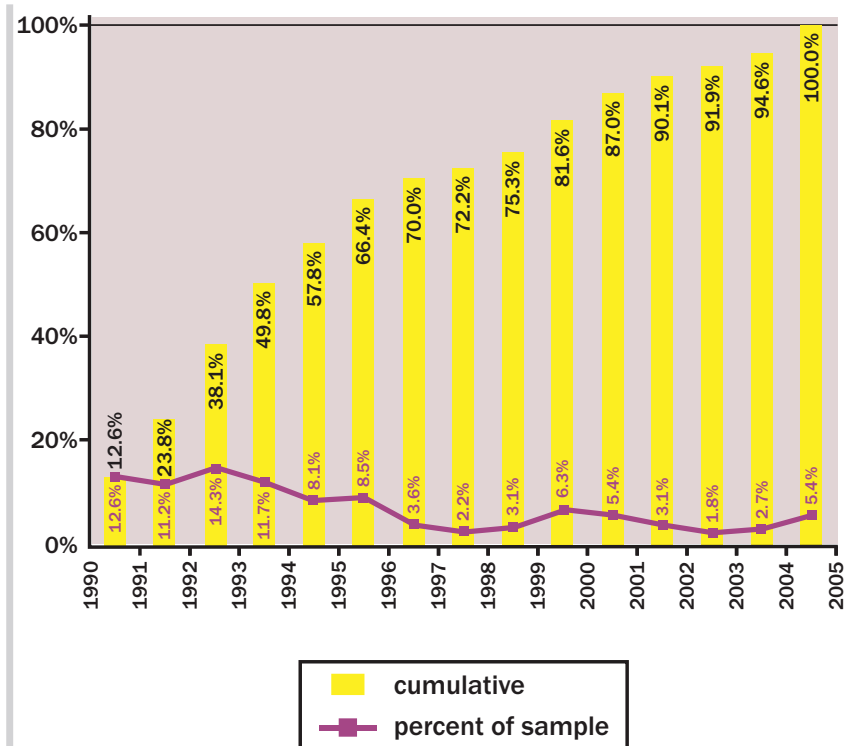

Graph 1.

Research sample - SME by year of founding 
market. On the other hand, only $20.6 \%$ of units in the sample were set up between 1995 and 2000; in the last four years it was a mere $13 \%$. Following the time factor, it seems there is a tendency for new units to be established at a slower rate. $C Z$ have the highest SME unit rate per 1000 inhabitants- in 2005 it was 230.8 (Kozak, 2006). These were mainly self employed persons.

We can divide units according to the scope of their business activities into enterprises operating in the following sectors: agriculture (2.2\%), industry and production (45.7\%), business (26.5\%) and services (25.6\%).

\subsection{Quantitative Research Area}

The main research goals were to describe entrepreneurial behavior under exogenous factor influence. These factors try to stimulate business activities in the region. The main research hypotheses were (in percentage share of the sample):

- Entrepreneurs prefer job-creation support (50\%) and ways of increasing their customer base (60\%),

- The main reason for closing down businesses is a lack of financial resources (70\% of the respondents),

- The main information source is not official statistics and analyses; this represents a decline in the quality of information received.

The frequency of individual factors in the research sample was used to identify individual factors. For relation determination we applied Cramer's contingency coefficient V (Cramer 1946), which represents the rate of most suitable association between two nominal variables. To interpret coefficient results we used Cohen's coefficient $V$ interpretation (1988)- a figure exceeding 0.5 signifies a strong dependence between variables; 0.5-0.3 average dependence; 0.3-0.1 low dependence and a figure below 0.1 zero dependence (Hintošová, Rimarčík, 2005).

\section{Taking Advantage of the Business Support System}

Taking into consideration exogenous factors, the support system plays an important role. Several areas which could motivate entrepreneurs to use this type of financing source have been identified. The main reason why entrepreneurs prepare their projects is to expand from local markets to another region (72\%), followed by new customer base building (65\%), job creation activities (45\%), acquiring quality certificates (30.5\%) and export support (29\%). On average entrepreneurs identify 2-3 factors as useful for development.
We were able to prove the hypothesis in the area of business support only partially, because the most important support area is expanding or finding new opportunities in other markets within the region (72\%), followed by finding a new customer base (65\%). Job-creation was not as preferred as we supposed in our hypothesis. From another point of view, we confirmed the average dependence between export support and the acquisition of certificates (Cramer $V=0,312 ; P<0,001$ ), where the influence of the EU quality regulations is evident.

\section{Factors Leading to the Closing down of Businesses.}

An exogenous factor which traditionally causes the end of business activities is a low supply of start up capital (69\%). In this case the set hypothesis has been proven true. The second factor comes from an increase in competition in the sector of their business activities (40.4\%). Another factor with lower significance was identified as bureaucracy when doing business (25\%) and the quality of the business environment (16\%). Gained factors could motivate SME owners positively; they could help them to become interested in the integration opportunities and take advantage of business cooperation. Financing availability and the quality of the business environment suggested an average dependence relationship. (Cramer $V=0,360 ; P<0,001)$

\section{Impact of Information Quality and Sources}

The last factors we examined were the sources and quality of business information available to SME owners. The initial hypothesis has been proven here, specifically that the best information source is one's own systematic sources (72\%), then manager informal affiliations (65\%), followed by official statistics (43.9\%) and custom-made analyses (22\%); on average two information sources are used.

In the area of information quality and reliability we have verified that these aspects have worsened since the EU accession (Cramer $V=0,554 ; P<0,001$ ) and many SME owners find information supply chaotic. The rate of association between these two periods has fallen by $10.2 \%$ in comparison with the period before $\mathrm{EU}$ accession (Cramer $\mathrm{V}=0,617 ; \mathrm{P}<0,001$ ).

\subsection{Factor Analysis}

To get more sophisticated results and to identify dominant tendencies, we used PCA with a VARIMAX rotation (factor loading minimization); the applicability of data was examined by Bartlett's test of sphericity for values from the results under $\mathrm{P}<0.05$; for other data we used the Kaiser-Meyer-Olkin Measure of Sampling Adequacy (KMO) with the recommended minimum value of 0.6 (Sharma, 1996). 
In the questionnaire we used a scale from one to six representing the time needed for entrepreneurs to respond to changes in certain factors (1-immediately, 6-period exceeding one year). Below we have analyzed endogenous factors such as managerial skills and competencies, strategy implementation, etc.

\section{Managerial Skills (MS)}

The research area covered 9 factors from a classic approach based on management functions, including corporate culture and the coordination skills of the unit owner. In $61 \%$ of examined units $(\mathrm{KMO}=0.854)$ the equation below represents the adequacy of managerial skills, where communicative activities are the most flexible; scale value 1.87 (up to one month).

$$
M S=f(M), f(A)
$$

where

$f(M)$... "Manager Factor", influenced mainly by organizing skills (0.846) and planning skills (0.789)

$f(A)$... Atmosphere Factor as the factor influencing social environment (0.855)

The research has proven that planning and organizational skills are very closely connected and guarantee the success of the strategy implementation as presented in the Classical school of management (correlation $=0.674$, Cramer $V=0.529 ; \mathrm{P}<0.001$ ).

\section{Strategic planning and its correction in time axis.}

The examined area was divided into two parts based on the hypothesis that EU accession had an influence on SME behavior in the market, consisting of 4 strategy components - marketing and human resource planning, financial and production plans. The level of data relevancy was more than $62 \%(\mathrm{KMO}=0.816)$ in both cases.

\begin{tabular}{|l|l|l|l|l|l|l|}
\hline Capacity or resource & $\begin{array}{c}\text { Creates } \\
\text { value? }\end{array}$ & Rare? & $\begin{array}{c}\text { Competitive } \\
\text { Imitable? }\end{array}$ & $\begin{array}{c}\text { Exploits a success } \\
\text { of SME? }\end{array}$ & $\begin{array}{c}\text { Econtion } \\
\text { Contribution }\end{array}$ \\
\hline SME specialization & Yes & In some ways & Yes & In some ways & Comparative Advantage \\
\hline $\begin{array}{l}\text { Customer relationship } \\
\text { management application }\end{array}$ & Yes & In some ways & Yes & In some ways & Comparative Advantage \\
\hline Image perception & Yes & Yes & Yes & In some ways & Long-term advantage \\
\hline Financial sources & Yes & In some ways & Yes & In some ways & Disadvantage \\
\hline Experience and knowledge & Yes & Yes & $\begin{array}{l}\text { In some } \\
\text { ways }\end{array}$ & In some ways \\
\hline
\end{tabular}

Table 4

Factor comparison by VRIO application in MS region

\section{Before the EU accession (2002-2004)}

PCA found only one dominating factor; all strategy was based on a marketing approach (0.818), where the correlation is 0.667 and Cramer $V=0,462 ;(P<0.001)$. The factor identified as a cause for changes in planning was financial planning - scale value of 3.46 (4.5 months).

\section{After the EU accession (2004-2006)}

The result seems to be the same. PCA found only one dominating factor; all the strategy is based on a marketing approach (0.843) with the most flexible being the financial area - a scale value of 3.24 (3.75 months).

After a comparison of the results we established that there was a growing trend of strategy dependence on a marketing approach after EU accession (correlation 0.693, Cramer V= $0.438 ; \mathrm{P}<0.001)$. This means that dynamics are on the rise by $5.6 \%$ compared with pre-accession planning.

\section{Discussion}

As stated above, the VRIO method was used to classify the resulting factors which lead to the improvement of competitiveness and the growth of advantages for an SME unit.

The V.R.I.O. model (Barney, 1991) looks for a competitive advantage of the entrepreneur's sources, which derive from the implemented analysis of endogenous factors. Each resource must answer the criteria and questions according to Barney. The advantage arises from resources, which have all four attributes (Cahlík-Sovina, 2003): 
- V (valuable) - ability to bring added value; sources, activities or processes which do not bring any advantage represent an economic disadvantage,

- R. (rare) and I. (imperfectly imitable) - imitability is based on different factors, such as unique materials or the abilities of available human capital,

- O (organization) -success depends on the organizational ability to exploit the advantage sufficiently. Without this attribute, you lose any advantage you may have.

SME units in the MS Region are easily imitable (international chains and network, identical products) and their main specializations are not rare. We may state that factors under the VRIO model are endogenous, such as managerial skills and the management of human resources, because they bring new ideas, innovative thinking and create a unique position for the unit in the market. They may take advantage of better dynamics and flexibility to changes in the business environment. The knowledge factor in SME development is closely connected to creating a good image and customer satisfaction. It is possible to state that the approach to the customer is the most important factor according to the VRIO analysis approach definition, and that this might be one of the most significant advantages for SME development.

Other unpredictable factors resulting from the current turbulent business environment may negatively or positively influence the long term sustainability of an advantage. Due to their existence, over time opportunities may change into disadvantages because of the growth of dynamics, as proven in the research (about 6\%).

\section{Conclusion}

Although we aim for a precise factor analysis, all the methods employed have their limitations and imperfections. The VRIO method, for example, does not take into account rapid changes or unpredictable circumstances which could cause significant changes in the entrepreneur's behavior. Gaining a competitive advantage in one market during a certain period does not necessarily result in the same development or outcome in another selected market. Moreover, we have to unify the analysis methodology (Antón-Pomeda, 1999):

\section{Branch->sub->branch->company->department->process.}

On the other hand, factor analysis or VRIO analysis application tries only to describe current processes and trends, to discover factors influencing business behavior to be adopted by real business units to support their creativity and strategic direction. Factors presented here should be divided into three main groups:

- Innovative potential included in the strategy; future training activities, management of human resources - all closely connected with endogenous factors,

- Dynamics and flexibility to changes in the business environment; these relate to the managerial skills, experience and knowledge of the SME unit team to completely determine the development of their company,

- Exogenous factors influencing the quality of information and financial sources necessary for development.

To summarize the level of strategy planning, we may claim that the main strategic power is in the hands of owners and managers (80\%), including the whole area of information and power over the entire business unit. When owners want to predict their future development, they trust mainly their own experience and scientific methods (70\%) against empirical studies or expert methods (30\%). The most frequent changes are observed mainly in production and finance planning (Hintošová, Rimarčík, 2005).

Examples of differences in strategic planning:

- Small companies have a simple linear organizational structure; the main power is in the hands of the owner. They depend on their sense of opportunities in the market,

- Adaptability depends on customers' needs - when they have a small customer base, its influence on behavior increases,

- SME companies are closely connected with the region; their behavior mirrors regional problems,

- SME units build their customer relationship approach into their strategy,

- SME units have to work with limited sources in their region,

- The definition of success is often influenced by the owner's vision, dreams and values,

o $\quad$ Negative attitude towards strategy planning 
\ Preference for short term planning.

These weaknesses could be bypassed by SME units through a proactive approach to improving their managerial skills or exploiting strategy methods useful to them personally, and emphasizing information base building that would enable them to connect training, research and experience in order to maximize profit. Considering the influence of financial support from the government, it is easier for the government to prepare grants rather than improve the business environment radically and, in doing so, provide the same opportunities for every entrepreneur.

\section{References}

Antón, José Miguel R., Pomeda, Jesús R., "Una Aplicación del análisis VRIO en el sector turístico Español: El caso de un hotel de Madrid" [14.11.2006], http://www.uam.es/personal_pdi/ economicas/pomeda/docs/analisis_vrio.doc.

Baumol, William, "Searching for the invisible man". The Economist Magazine, March 11, 2006, pp 67

Barney, Jay B. (1986), "Strategic Factor Markets: Expectations, Luck and Business Strategy", Management Science, Vol. $32, n^{\circ} 10,1231-1241$.

Barney, Jay B., "Gaining and Sustaining Competitive Advantage”. Reading. MA: Addison-Wesley, 1997. ISBN 0-20-1512858

Cahlík, Tomáš, Sovina, Jiří, "Konvergence a soutěžní výhody ČR”, Praha, 2003, [14.12.2006], http: //ies.fsv.cuni.cz/storage/ publication/286_wp_36.pdf.

Casson, M. (2005). "Entrepreneurship and the theory of the firm”. Journal of Economic Behavior \& Organization, 58 (2), 327-348

Czech Governement, Národní rozvojový plán České republiky, 2006 [20.12.2006], http://www.strukturalni-fondy.cz/index.php?show=000009009002008

Czech Statistical Office, "Small and Medium Sized Entreprises in the CZ", 2005 [12.12.2006], http://www.czso.cz/csu/ edicniplan.nsf/p/1138-06

Dierickx, Ingemar, Cool, Karel (1989). "Asset Stock Accumulation and Sustainability of Competitive Advantage", Management Science, Vol. 35, no 12, 1504-11.

Lippman, Steven A., Rumelt, Richard P. (1982), “Uncertain imitability: an analysis of interfirm differences in efficiency under competition", The Bell Journal of Economics, Vol. 13, 41838.
Hintošová, Aneta, Rimarčík, Marián, "Strategické správanie malých a stredných podnikov". In: Zborník vedeckých prác z medzinárodnej vedeckej konferencie Mladá veda 2005. Račkova dolina : Fakulta ekonomiky a manažmentu Slovenskej polnohospodárskej univerzity v Nitre, 2005. ISBN 80-8069673-X

Penrose, Edith, The Theory of the Growth of the Firm. 1st edition. New York :Wiley,1959

Slávik, Štefan, Romanová, Anita, "Predvídavosṫ a pružnosṫ podnikov. Výsledky prieskumu”, In: Nové trendy v podnikovom managemente, Košice: PHF EU Bratislava, 2005. ISBN 80969181-3-3

Slávik, Štefan , Strategický manažment. Bratislava, Ekonom 1997. ISBN 80-225-0816-0.

Sharma, Subhash, Applied Multivariate Techniques. New York: John Wiley \& Sons, 1996.

Vyakarnam, Shailendra, Leppard, John W., Plánování podnikatelských strategií. Praha, Grada,1998. ISBN 80-7169-533-5.

Wernerfelt, Birger, "A Resource-based View of the Firm". Strategic Management Journal, 1984 Vol. 5, 171-180. 